\title{
The Presence Of Rat And House Sanitation Associated With Leptospira sp. Bacterial Infection In Rats (A Cross Sectional Study In Semarang, Central Java Province, Indonesia)
}

\author{
Endang Setiyani ${ }^{1}$, Martini Martini $^{2}$, and Lintang Dian Saraswati ${ }^{2, *}$ \\ ${ }^{1}$ Animal Borne Disease Control Unit Banjarnegara, National Institute of Health Research and Development, Ministry of Health of \\ Republic of Indonesia, Jl. Selamanik 16A, Kutabanjarnegara, Banjarnegara, Indonesia, 53415 \\ ${ }^{2}$ Department Epidemiology and Tropical Diseases, Public Health Faculty, Diponegoro University, Semarang, 50275
}

\begin{abstract}
The Gajah Mungkur sub-district in Semarang, Indonesia had highest leptospirosis cases (reported in human with seven infected and one dead) in 2015. The purpose of this study was to analyze the association between house sanitation and density of rats with Leptospira $s p$. infection in rats. The study design was cross sectional observational analytic. The number of 308 trapswere placed in study sites over three consecutive nights afterwards. Every houses were placed with four traps, inside and outside. Trapped rats were anesthetized with atropine dose from 0.02 to $0.05 \mathrm{mg} / \mathrm{kg}$ body weight of rats continued with Ketamine HCL dose of 50-100 mg/kg body weight of rats by injecting in the thick thigh muscle of it. After that, identification of rats by species and gender then continues with surgery in which a kidney sample was taken to confirm the presence of bacteria Leptospirasp using PCR techniques. The trap installed in 77 houses which later had further observation on house sanitation which includes the existence of a pile of used goods, food storage, garbage can, and the presence of the ceiling, windows and other ventilation. Data was analyzed using distribution frequency and bivariate chi-square test. We had 100 rats captured with live traps as the samples.The proportion of Rattusnorvegicuswas $27 \%$ (14.8\% positive Leptospira sp.infection) and Rattustanezumi $73 \%$ (11\%positive Leptospira sp.infection). The proportion of male and female rats were almost equal. The statistic test result was significant between the density of rats $(p=0.0001$, OR 12.833 , 95\%CI: 1.565-105.261) and sex of rats $(\mathrm{p}=0.019$, OR 0.095, 95\% CI: 0.012-0.769) with Leptospira sp. infection in rats. The number of rats may increase the infection of Leptospirasp., especially female rats and poor condition of house sanitation. It is recommended to improve house sanitation and regularly trapping rats.
\end{abstract}

\section{Introduction}

Leptospirosis is neglected infectious disease caused by Leptospira bacterium infection, in group of Spirochaeta [1]-[3]. The advanced molecular techniques allowed the identification of 14 pathogenic and intermediately pathogenic species, and 7 non-pathogenic species, distinguishing three clades in Leptospira genus. These clades comprise more than 260 serovars. Among these, 7 species: L. interrogans, L. borgpetersenii, L. santarosai, L. noguchii, L. weilli, L. kirschneri and L. alexanderi are considered as the main agents of leptospirosis [4]-[9]. Portals of entry include cuts and abrasions or mucous membranes such as the conjunctival, oral, or genital surfaces. Exposure may occur through either direct contact with an infected animal or through indirect contact via soil or water contaminated with urine from an infected animal [8], [10]-[12].

In 2015, Gajah Mungkur district was one of highest case in Semarang within leptospirosis case. The data acquired in 2015 reported 7 patients and 1 died (CFR $=$ $16.67 \%$ ). Higest case found in Petompon and Sampangan Village. Both area was passed by river streams of West Flood Canal which made it possible as a vehicle of transmission of leptospirosis.

Leptospirosis is a good example of the interaction between humans and their environment, and particularly human interface with domestic animal. In the tropical climatic zone, where environmental conditions are most favourable for survival of leptospires and the highest morbidity is noted, extreme weather events such as cyclones and floods occurring in recent years with increasing frequency and greater intensity, may potentially result in an upsurge in the disease incidence, as well as the magnitude of leptospirosis outbreaks, such as our previous study [11]-[15]. Exposure to animals could be a potential risk factor for the disease. In the present study, rearing domestic animals at home was identified as a risk factor with an unadjusted OR of 1.21 (95\% CI: 1.02-1.43) [9]. The presence of rodents and

\footnotetext{
*Corresponding author: lintang.saraswati@live.undip.ac.id
} 
seeing more than five rats per day at home or work place were found to be risk [16], [17]. Practices such as use of vegetables ate by rats, contact with contaminated soil with rat's urine surrounding home were found to be highly associated as an independent factors [9], [13], [18]. Determination of Leptospira bacteria presence in mice are tested by using PCR (Polymerase Chain Reaction) with high sensitivity which reaches $90-100 \%$ approximately [4].

This study aims to determine the relationship of house sanitation and density of rats with bacterial infection by Leptopsira $s p$ in the subvillage Petompon and Sampangan in Gajah Mungkur District of Semarang.

\section{Methods}

\subsection{Study Design}

An analytic observational cross sectional study was conducted to estimate bacterial infection in rats and other related factor. The trap installed in 77 houses which later undertake further observations on house sanitation, which includes the existence of used goods piles, the existence of food storage, the presence of trash, the presence of the ceiling, windows condition and the presence of ventilation. The data is processed and statistically analyzed using the chi-square test to determine the relationship of home sanitation and density of mice with bacteria Leptospira sp infection in mice.

\subsection{Study Sites}

The study site were in Petompon village and Sampangan village located in Gajah Mungkur Sub-District in Semarang City.

\subsection{Population and Sample}

Population of the study were all rats lived at or nearby Petompon village and Sampangan village. Samples were captured at research sites using live traps.

We installed 308 trap in 77 houses on location over three consecutive nights afterwards. Every house installed with four traps, inside and outside of the house. The traps which caught rats or other animals like a shrew, mongoose, squirrels and other were taken and then replaced with empty traps which has been washed and dried. The caught rats put into a cloth bag, and then brought into field laboratories for the identification and PCR test. Other animals that caught were released, and the trap was immediately washed.

\subsection{Laboratory Testing}

Rats were anesthetized with atropine dose from 0.02 to $0.05 \mathrm{mg} / \mathrm{kg}$ body weight of rats continued with Ketamine HCL dose of 50-100 mg/kg. Body weight of rats by injecting in the thick thigh muscle of it The anaesthized rats were identified by species and gender then undergoes a surgery. Kidney sample was taken to confirm the presence of bacteria Leptospira with using PCR techniques.

\section{Results and Discussion}

\subsection{The existence of Rats.}

From the two variables was studied, there is one variable that showed a significant relationship with the bacteria Leptospirasp infection in mice, the sex of mice (Table 1 ). Gender mice with $\mathrm{p} \leq 0.05$ and value $\mathrm{OR}=0.095$, it means that the sexes of mice not a risk factor for the infection of bacteria Leptospira sp. in mice. Based on the results of catching rats, 100 rats caught split by mostly 56 a female, so the female rats had higher activity than male rats. This is in line with previous studies, female rats were more common than the male rats [19]-[21]. Female rats have the nature of post-partum oestrus (estrus ability mother after giving birth). One to two days after giving birth, the mother ready to marry male rats [22]. This further increased the Leptospira bacteria in mice.

The mean life time of in days of the males rats $628 \pm 17.3$ and the female rats $707 \pm 15.9$ [22] It can be said the life span of female mice longer than male rats, so the possibility of female rats exposed to the bacteria Leptospira has longer [23], [24].

The genders of mice that were caught in this study, can be used to determine the mobility of the population of rats in a residential area. Activities of mice is usually aim for eating, drinking, sex, and orientation of the range region. During the orientation area, these animals will recognize the environmental situation especially preferred feeding areas, water, and shelter to save themselves [15], [24]-[26].

Table 1. Identification of captured rats and Leptospira sp Bacterial Infections in Rats at Petompon and Sampangan Village 2016

\begin{tabular}{|c|c|c|c|c|c|c|c|c|c|}
\hline \multirow{3}{*}{\multicolumn{2}{|c|}{ Variable and Category }} & \multicolumn{4}{|c|}{$\begin{array}{l}\text { Leptospira sp bacterial infection } \\
\text { in mouse }\end{array}$} & \multirow{2}{*}{\multicolumn{2}{|c|}{ Total }} & \multirow{3}{*}{$\begin{array}{c}\text { Value } \\
\mathbf{p}\end{array}$} & \multirow{3}{*}{$\begin{array}{c}\text { OR } \\
(95 \% \mathrm{CI})\end{array}$} \\
\hline & & \multicolumn{2}{|c|}{$\begin{array}{c}\text { Positive } \\
(n=12)\end{array}$} & \multicolumn{2}{|c|}{$\begin{array}{c}\text { Negative } \\
(\mathbf{n}=88)\end{array}$} & & & & \\
\hline & & f & $\%$ & f & $\%$ & f & $\%$ & & \\
\hline \multicolumn{10}{|l|}{ Species } \\
\hline \multirow{2}{*}{-} & \multirow{2}{*}{$\begin{array}{l}\text { Rattus norvegicus } \\
\text { Rattus tanezumi }\end{array}$} & 4 & 14.8 & 23 & 85.2 & 27 & 100 & \multirow[t]{2}{*}{0.750} & \multirow{2}{*}{$\begin{array}{c}1.413 \\
(0.389-5.38)\end{array}$} \\
\hline & & 8 & 11.0 & 65 & 89.0 & 73 & 100 & & \\
\hline \multicolumn{10}{|l|}{ Gender } \\
\hline- & Male & 1 & 2.3 & 43 & 93.7 & 44 & 100 & 0.019 & 0.095 \\
\hline - & Female & 11 & 19.6 & 45 & 80.4 & 56 & 100 & * & $(0.012-0.769)$ \\
\hline
\end{tabular}




\subsection{House Sanitation}

Of the seven variables studied, only one variable that showed a significant relationship with the bacterium Leptospira sp infection in mice that the density of the mice in the house. The density of rats with $p \leq$ value of 0.05 and value $\mathrm{OR}=12.8$, means that the house is solid rat has a 12.8 times greater risk of occurrence of
Leptospira positive bacterial infections in mice compared to a house without mouse. With the discovery of mice in residential areas, may increase the occurrence of bacterial infections Leptospira sp. in mice. A recent study indicated that young non reproductive rats, which had just left the nest, showed a prevalence of up to $30 \%$ of kidney colonization [4], [27].

Tabel 2. House Sanitation and Leptospira sp Bacterial Infections in Rats at Petompon and Sampangan Village 2016.

\begin{tabular}{|c|c|c|c|c|c|c|c|c|}
\hline \multirow{3}{*}{ VariabledanCategory } & \multicolumn{4}{|c|}{$\begin{array}{l}\text { Leptospira sp bacterial } \\
\text { infection in mouse }\end{array}$} & \multirow{2}{*}{\multicolumn{2}{|c|}{ Total }} & \multirow{2}{*}{ Nilai } & \multirow{3}{*}{$\begin{array}{c}\text { OR } \\
(95 \% \text { CI) }\end{array}$} \\
\hline & \multicolumn{2}{|c|}{ Positif $(n=12)$} & \multicolumn{2}{|c|}{$\begin{array}{r}\text { Negatif } \\
(\mathrm{n}=65)\end{array}$} & & & & \\
\hline & $\mathbf{f}$ & $\%$ & $\mathbf{f}$ & $\%$ & $\mathbf{f}$ & $\%$ & $\mathbf{P}$ & \\
\hline \multicolumn{9}{|l|}{ Piles of used goods } \\
\hline a. Yes & 10 & 14.5 & 59 & 85.5 & 69 & 100 & \multirow[t]{2}{*}{0.603} & 0.508 \\
\hline b. No & 2 & 25.0 & 6 & 75.0 & 8 & 100 & & $(0.090-2.883)$ \\
\hline \multicolumn{9}{|l|}{ Food storage } \\
\hline a. Open & 8 & 14.0 & 49 & 86.0 & 57 & 100 & \multirow[t]{2}{*}{0.498} & 0.653 \\
\hline b. Covered & 4 & 20.0 & 16 & 80.0 & 20 & 100 & & $(0.173-2.460)$ \\
\hline \multicolumn{9}{|l|}{ Garbage can } \\
\hline a. Open & 10 & 16.1 & 52 & 83.9 & 62 & 100 & \multirow[t]{2}{*}{0.9} & 1.250 \\
\hline b. Covered & 2 & 13.3 & 13 & 86.7 & 15 & 100 & & $(0.244-6.414)$ \\
\hline \multicolumn{9}{|l|}{ Ceiling } \\
\hline a. No & 3 & 27.3 & 8 & 72.7 & 11 & 100 & \multirow{3}{*}{0.363} & 2.375 \\
\hline b. Yes & 9 & 13.6 & 57 & 86.4 & 66 & 100 & & $(0.529-10.661)$ \\
\hline \multicolumn{8}{|l|}{ Window } & \\
\hline a. Not tightly fitted & 1 & 11.1 & 8 & 88.9 & 9 & 100 & \multirow[t]{2}{*}{0.9} & 0.648 \\
\hline b. Tightly fitted & 11 & 16.2 & 57 & 83.8 & 68 & 100 & & $(0.073-5.711)$ \\
\hline \multicolumn{9}{|l|}{ Ventilation } \\
\hline a. Open & 11 & 16.4 & 56 & 83.6 & 67 & 100 & \multirow[t]{2}{*}{0.9} & 1.768 \\
\hline b. Covered & 1 & 10.0 & 9 & 90.0 & 10 & 100 & & $(0.203-15.402)$ \\
\hline \multicolumn{9}{|l|}{ Population dens ity of mouse/rats } \\
\hline a. $\quad \operatorname{High}(>7 \%)$ & 12 & 29.3 & 29 & 70.0 & 41 & 100 & 0.0001 & 12.833 \\
\hline b. $\quad$ Low $(<7 \%)$ & 0 & 0 & 36 & 100 & 36 & 100 & * & $(1.565-105.261)$ \\
\hline
\end{tabular}

Infection at a very young age ( $>2$ months) suggests that transmission may occur also in utero or to neonates, possibly through infectious milk, or by other routes within the nest including close contact with an infected mother via fomites or uro-genital cleansing of neonates by the dam [22], [21], [28], [24].

In this study, the success of catching rats (Trap success) is as high as $11 \%$. The success of catching mice at home habitat is when more than $7 \%$ [4], [22], [21]. With the success of these arrests rate, can illustrate that the research sites have high density rats population as a potential transmission of leptospirosis. Leptospira bacteria infection occurred because a lot of rats were found in residential areas so in this case, contamination by rat urine, will be easily affected leptospirosis case in human .

The high density of the mice in this study, it is possible for a distance of one another house huddled together with poor sanitary conditions so that the house can live rats and mice in the house proliferate [13], [15], [25]. The existence of mice in the house is very dangerous to humans because rats was the main reservoir of leptospirosis disease. Leptospirosis can be debilitating, particularly for the young and old, and severe cases can lead to liver and kidney failure and internal bleeding
(Weil's syndrome) [1], [3], [29]. Indeed, there are many diseases transmitted by rodents either through rodent faeces (salmonella), urine (leptospirosis) airborne viruses (haemorraghic fever) and vector insects (plague and murine typhus). Considering the close proximity rodents have with humans in these environments, many rodent diseases are likely to be having debilitating effects which reduce productivity and cause mortality [9], [13], [29].The presence of rats in a residential area needs serious attention, as a form of awareness of disease transmission, especially leptospirosis.

\section{Conclusion}

Based on the results of the analysis can be seen that there is a significant correlation between the density of rats $(p$ $=0.0001)$, Gender of rats $(p=0.019)$ with infection of bacteria Leptospira sp. in rats and there was no significant correlation between rat species, piles of junk, used to store food, trash, where the ceiling, where the windows and the presence of bacterial infection ventilation with Leptospira sp. in mice. Advice to the Community to keep the house in order clean for not to become a breeding ground for rats and mice catching efforts regularly and continuously to reduce the rat 
population, especially in Subvillage Petompon and Sampangan.

\section{References}

1. T. Fraga, E. Carvalho, L. Isaac, and A. Barbosa, "Leptospira and Leptospirosis," in Molecular medical microbiology, 2nd Ed., Y.-W. Tang, M. Sussman, D. Liu, I. Poxton, and J. Schwartzman, Eds. Elsevier, pp. 1973-1990, (2014).

2. D. A. Haake and P. N. Levett, "Leptospirosis in Humans," Curr. Top. Microbiol. Immunol., vol. 387, pp. 65-97, (2015).

3. A. J. Mcbride, D. Athanazio, M. Reis, and A. I. Ko, "Leptospirosis," Leptospirosis Curr. Opin. Infect. Dis., vol. 18, no. 5, pp. 376-386, (2005).

4. U. Kositanont, P. Naigowit, A. Imvithaya, C. Singchai, and P. Puthavathana, J. Med. Assoc. Thai., vol. 86, no. 2, pp. 136-42, Feb. (2003).

5. D. Benacer et al., Parasit. Vectors, vol. 9, no. 1, p. 117, Dec. (2016).

6. J. P. dos Santos et al., Trop. Anim. Health Prod., vol. 44, no. 1, pp. 101-6, Jan. (2012).

7. S. M. de Carvalho, A. L. B. B. Mineiro, V. Castro, M. E. Genovez, S. S. Azevedo, and F. A. L. Costa, Trop. Anim. Health Prod., vol. 46, no. 2, pp. 491-4, Feb. (2014).

8. A. Dreyfus et al., PLoS Negl. Trop. Dis., vol. 10, no. 8, p. e0004858, Aug. (2016).

9. M. Lelu, C. Muñoz-Zanzi, B. Higgins, and R. Galloway, BMC Vet. Res., vol. 11, p. 31, (2015).

10. M. P. Ward, L. F. Guptill, and C. C. Wu, J. Am. Vet. Med. Assoc., vol. 225, no. 1, pp. 72-77, Jul. (2004).

11. A. P. Sugunan et al., Indian J. Med. Res., vol. 130, no. 1, pp. 67-73, Jul. (2009).

12. A. M. Dechet et al., PLoS One, vol. 7, no. 7, p. e39672, Jul. (2012).

13. R. K. Raghavan, K. M. Brenner, J. J. Higgins, J. M. Shawn Hutchinson, and K. R. Harkin, Prev. Vet. Med., vol. 106, no. 3-4, pp. 324-31, Oct. (2012).
14. S. C. Sehgal, A. P. Sugunan, and P. Vijayachari, Natl. Med. J. India, vol. 15, no. 1, pp. 22-3, (1995).

15. S. N. Fajriyah, A. Udiyono, and L. D. Saraswati, in IOP Conference Series: Earth and Environmental Science, 2017, vol. 55, no. 1, (2017).

16. J. G. Songer, C. J. Chilelli, R. E. Reed, and R. J. Trautman, Am. J. Vet. Res., vol. 44, no. 10, pp. 1973-6, Oct. (1983).

17. B. Wasiński, Przegląd Epidemiol, vol. 65, no. 3, pp. 471-6, (2011).

18. P. Vijayachari, A. P. Sugunan, and A. N. Shriram, J. Biosci., vol. 33, no. 4, pp. 557-69, Nov. (2008).

19. F. Costa et al., Vector-Borne Zoonotic Dis., vol. 14, no. 1, pp. 33-40, Jan. (2014).

20. F. Costa et al., PLoS Negl. Trop. Dis., vol. 9, no. 6, p. e0003819, Jun. (2015).

21. L. H. Krøjgaard, S. Villumsen, M. D. K. Markussen, J. S. Jensen, H. Leirs, and A.-C. Heiberg, Epidemiol. Infect., vol. 137, no. 11, pp. 1586-92, Nov. (2009).

22. C. G. Himsworth, K. L. Parsons, C. Jardine, and D. M. Patrick, Vector-Borne Zoonotic Dis., vol. 13, no. 6, pp. 349-359, Jun. (2013).

23. C. G. Himsworth, K. L. Parsons, C. Jardine, and D. M. Patrick, Vector-Borne Zoonotic Dis., vol. 13, no. 6, pp. 349-359, Jun.(2013).

24. C. G. Himsworth et al., PLoS Negl. Trop. Dis., vol. 7, no. 6, p. e2270, Jun. (2013).

25. F. Costa et al., PLoS Negl. Trop. Dis., vol. 8, no. 12, p. e3338, Dec. (2014).

26. M. A. S. Johnson et al., Emerg. Infect. Dis., vol. 10, no. 6, pp. 1016-22, Jun. (2004).

27. C. A. Ganoza et al., PLoS Med., vol. 3, no. 8, p. e308, Aug. (2006).

28. M. Runge et al., Pest Manag. Sci., vol. 69, no. 3, pp. 403-408, Mar. (2013)

29. P. N. Levett, "Systematics of Leptospiraceae," in Leptospira and Leptospirosis, 1 st Ed., B. Adler, Ed. Springer-Verlag Berlin Heidelberg, pp. 11-20, (2015). 